http://www.jfas.info

\title{
THE USE OF FUZZY REAL OPTION VALUATION METHOD TO RANK GIGA INVESTMENT PROJECTS ON IRAN'S NATURAL GAS RESERVES
}

\author{
Y. Servati ${ }^{1}$, S. Hassan Ghodsypour ${ }^{2} *$, M. A. Shirazi ${ }^{3}$ \\ ${ }^{1} \mathrm{Ph} . \mathrm{D}$. Candidate of Industrial Engineering, Amirkabir University of Technology, Tehran, \\ Iran \\ ${ }^{2}$ Industrial Engineering and Management Systems Department, Faculty of Industrial \\ Engineering and Management Systems Dep, Amirkabir University of Technology, Tehran, \\ Iran \\ ${ }^{3}$ Faculty of Industrial Engineering and Management Systems Dep., Amirkabir University of \\ Technology, Tehran, Iran,
}

Published online: 15 February 2017

\begin{abstract}
Giga investments are exposed to numerous systematic and unsystematic (or specific) risks that significantly influence their feasibility and value. In addition to the conventional issues and complexities in evaluating investment projects, factors such as long construction time, high amount of capital required and irreversibility of investment, increase uncertainty of cash flows in these types of projects. As a consequence, decision makers are usually not satisfied with the results of the most popular valuation methodology - discounted cash flow analysis in valuation of Giga investments. The most promising methodology of valuing flexibility in such investment projects is the real options valuation which quantifies the value of embedded flexibilities through option pricing techniques.

In this paper, fuzzy real options valuation techniques are used to rank Giga project proposals faced in Iran's gas industry. To this end, different scenarios of project payoff and future uncertainties are quantified, using fuzzy numbers based on findings from earlier real option valuation methods.
\end{abstract}

Keywords: Giga Investment, Fuzzy Pay Off, Real options valuation, Natural Gas, Iran

Author Correspondence, e-mail: ghodsypo@aut.ac.ir

doi: http://dx.doi.org/10.4314/jfas.v9i1s.680 


\section{INTRODUCTION}

Giga projects are projects that create specific and complex requirements for policy-makers and programmers given the size of the actual investment required (sometimes more than $\$ 1$ billion) and time required to achieve the output and return on investment[1]. Programming and technical and economic forecasts are of great importance in the success of these projects, and since these projects are generally irreversible and finding customer for these projects is so difficult (and sometimes impossible) in the case of their failure, in addition to the usual methods of financial evaluation (including common methods of analysis of the present value of the investment), analysts should use more advanced techniques to analyze future revenues and costs of the projects. On the other hand, Giga projects are likely to affect the environment, and sometimes they may cause serious changes in pricing and their products market. In fact, the use of the concept of price-taker behavior for economic analysis of the projects' future earnings may put analysts in trouble.

Investment in upstream oil, gas and petrochemical projects is generally made in the scales of Giga investment. Due to the aspects of economic, social and even cultural effects on their environment, these projects should be studied carefully and decision-making should be done on the basis of all circumstances facing the projects. Investment in oil and gas projects is generally a long-term investment with a very long life cycle (about 10 years or more), and no dramatic changes can be done in the specifications of the output after the start of the project and therefore, technical and economic forecasts are to be made before the start of the project. According to the latest reports of BP, Iran is the world's largest holder of natural gas reserves[2]. Despite its huge amount of reserves, Iran ranks fourth among leading manufacturers in the world due to inadequate investment in upstream natural gas production [3]. Lack of investment has caused Iran irreparable damages because of the loss of its share in the common areas (including the joint South Pars gas field with Qatar)[4]. However, share of production for export is not much due to the uncontrolled growth of domestic consumption and Iran has failed to properly use the great economic potential of its resources. Accordingly, there are different investment projects and recommendations to develop upstream use of gas reserves by National Iranian Gas Company, all of which require high investment amounts and much time for their productivity. There are financial resources limitations (due to reduced oil revenues and foreign restrictions on trade and foreign investment in the country) to start all mentioned projects. So, the right tools and methodologies for Giga investment analysis must be used to prioritize investment in this sector. 
In this paper, the available information on the investment required and future earnings of the projects are used with the future trend of world oil and natural gas prices, to provide real option value of projects. To this end, fuzzy payoff logic is used as a real option valuation tool. Prices and conditions facing raw materials and consumption market of the projects are evaluated at 3 pessimistic, optimistic and possible levels and finally investments in each of these projects are prioritized with a financial assessment approach. In order to facilitate the presentation of the results in this paper, it is assumed that fixed investment required during the project is done according to preliminary forecast and changes just will be made in the raw material and product market of projects. Other environmental risks of the projects are ignored.

In the next sections, in addition to the detailed explanations of systematic and unsystematic (or specific) risks influencing feasibility and value of Giga projects, different aspects of proposed projects to invest in Iran's gas industry are introduced. Then, the fuzzy pay off method is introduced as a real option valuation tool for prioritizing projects using 3 pessimistic, possible, and optimistic scenarios. At the end, the analysis of the results and recommendations to complement and enhance the accuracy of the results of this research are presented.

\subsection{Giga Investment (Projects)}

Giga investment means investing in projects that require heavy financial resources for the project start up (over 100 million euros). In this kind of projects, the time required to carry out the project and to start its operation is so long[1]. In some cases, this will take time between several months to several years. However, the operation time of these projects is usually long so that it may take over 50 years in some cases (such as the production of an oil well or a mine). One of the most important issues facing these kinds of investment is uncertainty caused by changes in the environment and prices of raw materials and products resulting from these projects. Because in the traditional calculation methods such as the net present value or discounting future cash flows all factors are considered to be definitive and changes in them can make great changes in the results of the analysis. Another problem encountered in the analysis of investment in Giga projects is their impact on the environment, such that as a result of their implementation, many fundamental changes are made in the consumer and raw materials market[5]. For example, investment in order to build a power plant in the free market can increase the supply of electricity and as a result affect the consumer market and product selling price[6], and therefore the potential effects of the 
project on the future demand and market prices at the time of operation of the project will have a significant role in the economic analysis of projects[7].

One of the main characteristics of the investment in Giga projects is irreversibility of much of the initial investment after the start of the project. That means that if the investor wants to stop the Giga project for any reason, the initial investments and equipment related to these projects are not to be sold easily, since they have fundamentally been designed and prepared for that project. That is, after the start of the project, it cannot be decided to stop the Giga project without taking into account a significant loss. Collan [1] has talked about the characteristics of these projects in detail in his article.

As shown in Figure 1, Giga projects have 3 life cycles and as a result, 3 investment valuation methods. According to the life cycle in which the project is, analysts should use tools specific for each cycle in order to analyze investment. For example, given that the project's operating costs have not yet started and just the cost of planning is imposed on the project and also there is a possibility (option) decide whether to start the project or not, real option valuation mechanism should be used to analyze investment before the start of the project. But given the irreversibility of Giga projects after their start and that the cash flow in this stage is only in the form of (fixed) cost and also revenues are also characterized by uncertainty, analysis method changes to real forward valuation[1]. In order to evaluate projects under equal conditions in this study, all the projects have been considered in the first phase (planning stage) and therefore the real option valuation method is used to analyze and prioritize them. Following the introduction of fuzzy numbers, fuzzy pay off approach is presented for real option valuation.
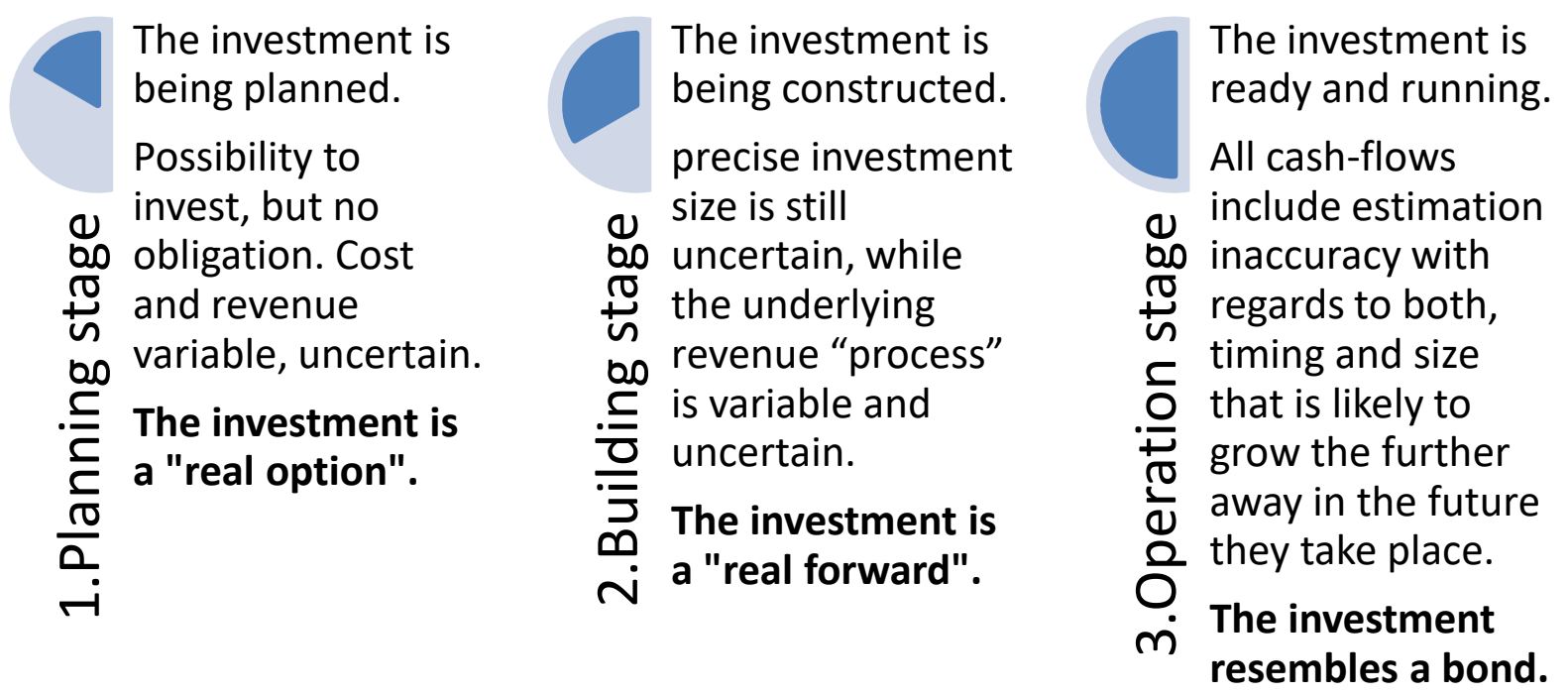

Fig.1. Life cycles of a Giga project and investment valuation method in each period [1] 


\subsection{Fuzzy pay off method for real options valuation}

In fact, real options are the translation of the financial authorities used in real projects to enhance the flexibility of management decisions. Using this approach in large investment projects is increasingly welcomed by researchers because of the uncertainty of costs and future revenues of investment. Real options valuation is based on theoretical principles and procedures governing the valuation of financial authorities, such as the Black-Sholes method $[8,9]$ or binomial trees $[10,11]$. The use of these methods in practice is so complex due to the restrictions for the use of these methods. Therefore, in recent studies, researchers have focused on presenting models with simple calculations and have yet reliable results [12$16]$.

In recent papers a practical probability theory-based Datar-Mathews method for the calculation of real option value is proposed[17, 18]. Authors demonstrate that the method and results from the method are mathematically equivalent to the Black-Sholes formula. The method is based on simulation-generated probability distributions for the NPV of future project outcomes and it shows the real-option value can be understood as probabilityweighted average of the pay-off distribution. More details can be found in [17]. Collan merges this concept with fuzzy set theory. He uses fuzzy numbers in representing the expected future distribution of possible project costs and revenues, and hence also the profitability NPV outcomes[19].

In the following, in addition to a brief introduction of fuzzy numbers, the fuzzy pay off model is briefly described for real option valuation with emphasize on its application in mega investments valuation.

\subsubsection{Fuzzy sets}

Fuzzy sets, introduced by Zadeh in 1965[20], provide a new mathematical tool to deal with uncertainty of information. Since then, fuzzy set theory has been rapidly developed and many successful real applications of fuzzy sets and systems in wide-ranging fields have emerged(eg.Şengül, Eren [21]). A fuzzy set $\tilde{A}$ of $\mathrm{X}$ is defined by its membership function when $X$ is a universal set.

$$
u_{\widetilde{\mathrm{A}}}: \mathrm{X} \rightarrow[0,1] ; \mathrm{X} \sim \widetilde{\mathrm{A}}(\mathrm{x})[0,1]
$$

The value of $\mu_{\widetilde{\mathrm{A}}}(\mathrm{x})$ represents the grade of membership of $x$ in $X$ and is interpreted as the degree to which $x$ belongs to $\widetilde{\mathrm{A}}$ therefore the closer the value of $\widetilde{\mathrm{A}}(\mathrm{x})$ to 1 , the more its belonging to $\widetilde{A}[22]$. A fuzzy set $\widetilde{A}$ can be characterized as a set of ordered pairs of elements $x$ and grade $\widetilde{\mathrm{A}}(\mathrm{x})$ and is noted as: 


$$
\tilde{A}=\left[\left(x, \mu_{\widetilde{\mathrm{A}}}(\mathrm{x})\right) \mid \mathrm{x} \in \mathrm{X}\right]
$$

Basic notions and Operations and properties of fuzzy sets can be found in the literature[22]. Following the introduction of fuzzy sets in the following paragraphs, Fuzzy Pay-off method for evaluation of real options is briefly explained.

\subsubsection{Fuzzy Payoff Method}

Mezei, Collan and Fullér used different revenue and cost scenarios in the form of ideal, possible and pessimistic conditions and a fuzzy number to portray the future distribution of revenues and the cost of the project (and thus the distribution of profits) in their proposed method[19]. This method valuates projects citing that weighted average of positive outcomes of the income distribution is considered as the real option price[17] and with the use of the fuzzy mean value calculation [23].

Calculation of the real option value by this method can be simplified into the following:

$$
R O V=\frac{\int_{0}^{+\infty} A(x) d x}{\int_{-\infty}^{+\infty} A(x) d x} \times E\left(A_{+}\right)
$$

In which the likelihood or the possibility (in terms of the area under the possibility distribution of the investment outcome being on the positive side of the NPV distribution) is multiplied by the expected value, or the central measure, of the positive side of the estimated investment NPV distribution.

In this paper, the triangular fuzzy numbers in figure 2 are used to show the distribution of revenues made by implementation of mega-projects of Iran's gas resources.



Fig.2. distribution of revenues from the implementation mega-projects in the form of triangular fuzzy number

In this regard, 3 numbers should be selected as the most expected limit, the most likely limit and the least expected limit to map the distribution of income and expenses of mega-projects. According to long-time implementation and operation of mega-investments, estimates change 
over time and create different conditions for investors. Figure 3 schematically shows the fuzzy estimates changes in income and costs' distribution of mega-investments.
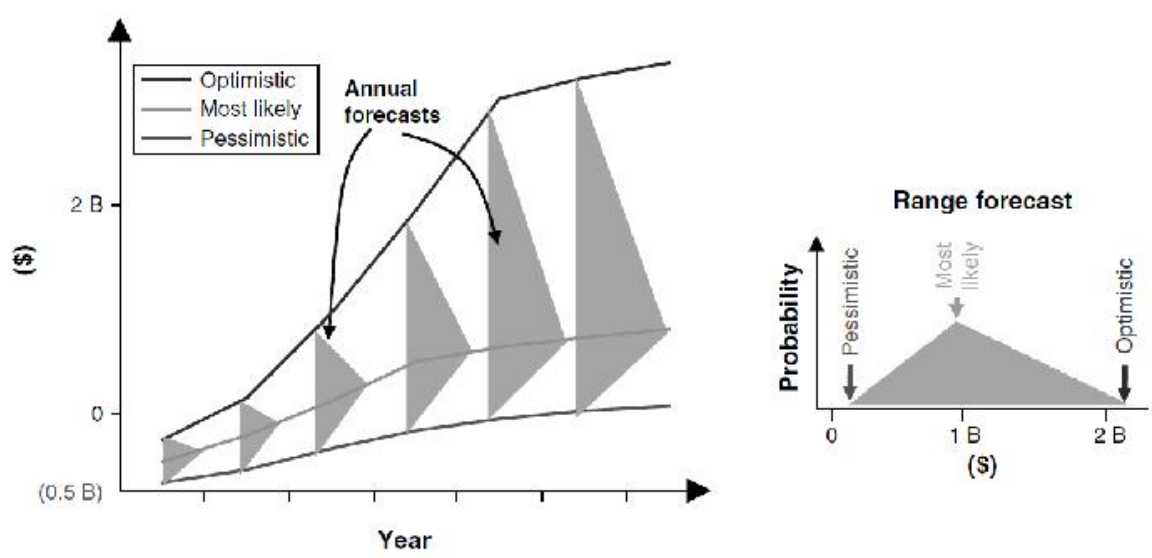

(S)

Fig.3. Changes of fuzzy estimates made for the distribution of revenues from mega investments [24]

The ROV is found by calculating the area of the positive side shown in figure 2 , divided by the entire area of the triangle and then multiplied by the fuzzy mean value of the positive side of the fuzzy distribution $\left(E\left(A_{+}\right)\right)$.

Authors of fuzzy pay off model have proposed four formulas for calculating $\mathrm{E}\left(\mathrm{A}_{+}\right)$using the formula provided by Carlsson and Fullér[23]. These formulas are used according to the various conditions that can govern a, $\alpha$, and $\beta$. The formula for calculating $E\left(\mathrm{~A}_{+}\right)$in four different modes is presented below[19].

First case is where the whole fuzzy distribution is above zero, when $0<(a-\alpha)$. The mean value of the positive area is calculated as:

$$
E\left(A_{+}\right)=a+\frac{\beta-\alpha}{6}
$$

Second case is where the fuzzy distribution is partly above zero, which means that is above zero but $(\mathrm{a}-\alpha)$ is below zero $(\mathrm{a}-\alpha<0<\mathrm{a})$. In this case the mean value of the positive area is calculated as

$$
E\left(A_{+}\right)=a+\frac{\beta-\alpha}{6}+\frac{(\alpha-a)^{3}}{6 \alpha^{2}}
$$

Third case is where fuzzy distribution is partly above zero, but with the centre, a, below zero but $a+\beta$ still above zero $(a<0<a+\beta)$. The mean value of the positive area in this case is calculated as

$$
E\left(A_{+}\right)=\frac{(\alpha+\beta)^{3}}{6 \beta^{2}}
$$


Fourth case is when the whole fuzzy distribution is below zero. The mean value of the positive area in this case would be equal to zero.

More details on calculation of the fuzzy real option value can be seen at [25] .

2. Ranking Iran's Natural gas export Giga investment opportunities

According to the latest estimations of British Petroleum Company, Iran with $18.2 \%$ natural gas reservoirs has the first natural gas reservoirs in the world[2]. In terms of natural gas production, Iran with 166.6 million $\mathrm{m}^{3}$ in 2014 has the only $5 \%$ of total natural gas in the world and this value is reduced $0.2 \%$ compared to 2013 [3]. It is worth to mention that of this value, only about $5 \%$ (9.28 billion $\mathrm{m} 3$ ) is dedicated to natural gas export[26]. In ranking the major manufacturers of natural gas in the world, Iran has fourth rank with a considerable distance from US and Russia (figure 4) .This shows that despite considerable natural gas resources, Iran didn't produce and operate these resources for different reasons. Based on the growing trend of natural gas production in Qatar, it is expected that the distance between Iran and Qatar is increased for the benefit of Qatar. At the same time, high share of gas consumption in the country has caused that Iran is not in the list of 20 first countries for natural gas exporting in the world[3].

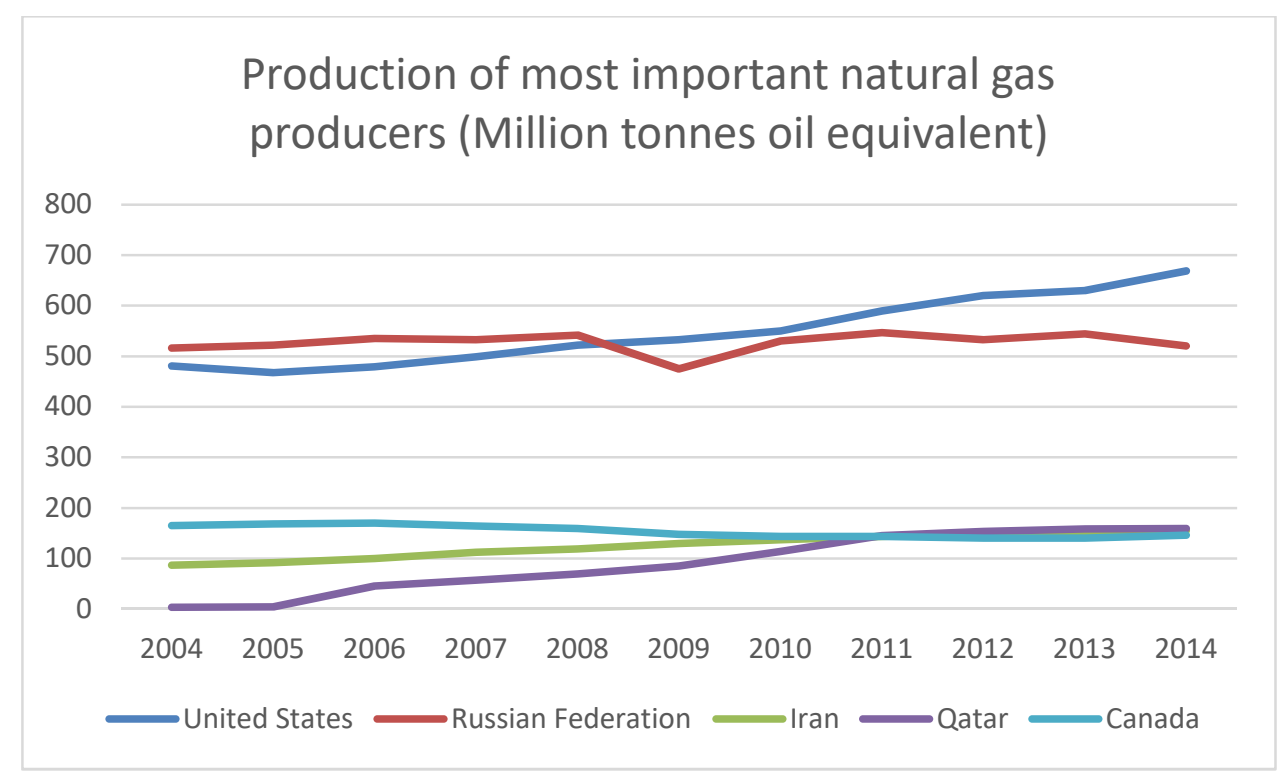

Fig.4. Production of most important natural gas producers[2]

On the other hand, due to huge reserves of gas and over 100 years of experience in the extraction and export of petroleum products as well as great access to consumption markets, Iran is of high potential to develop upstream and downstream natural gas mega-projects. However, due to government restrictions on the funding needed to launch all Giga projects defined in the gas industry as well as lack of sufficient private sector's role to finance 
projects, it is necessary to investigate and prioritize these projects in terms of economic factors. Using real options pricing method and fuzzy pay-off method, some of Giga-projects defined in the gas industry have been evaluated and prioritized in this paper. In order to assimilate the results, all projects are assumed to be in the initial phase of decision making and just the effect of changes in oil prices, natural gas and petroleum products on projects and the selling price of their products are considered as the source of uncertainty in future income of the Giga project. The scenarios facing the oil and natural gas in 25-year time horizon (until 2040) are presented below and then the selected Giga projects to be evaluated in this study and the potential benefits of each of them have been introduced.

\subsection{Future scenarios of global oil and natural gas price}

Figure 5 shows the different scenarios facing the international price of Brent crude[27]. These scenarios have been designed taking into account the factors causing uncertainty in the futures price of oil. Factors such as changes in global demand for crude oil and other petroleum products, crude oil production and providing other liquid fuels are included in designing these scenarios. This paper aims to valuate revenues from Giga-investments facing the natural gas industry in Iran using the real options theory. The scenarios of High oil price, Reference and Low oil price have been used to create triangular fuzzy numbers as an indicator of mega-investment revenues. Prices associated with these three scenarios, in fact, represent high, low and possible limits of futures prices of crude oil that have been used to create cost and revenue scenarios of Giga-investments in this article.

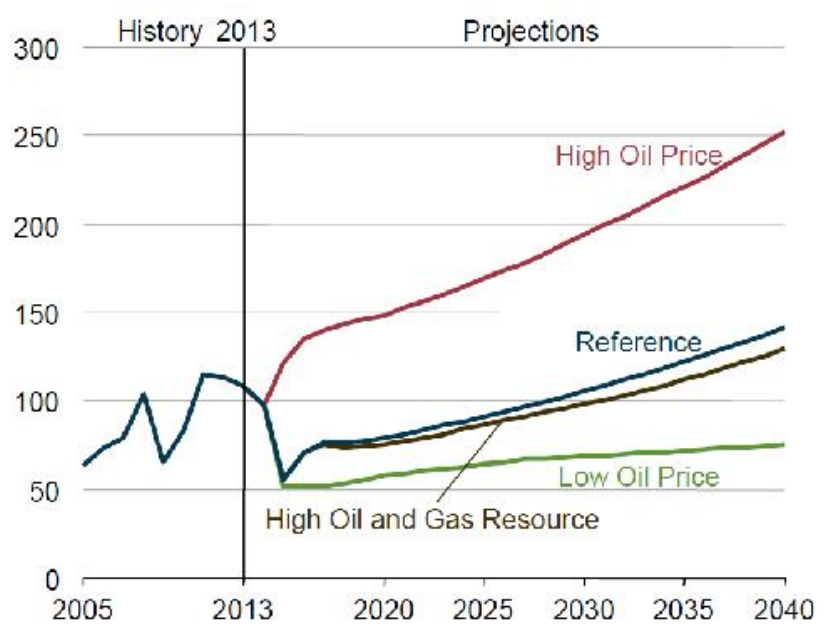

Fig.5. North Sea Brent crude oil spot prices in four cases (dollars per barrel)[27]

Henry Hub spot price in America is also used as a reference in order to assess the cost of feed ingredient and the export price of natural gas in the valuation of future revenues of Giga- 
projects in Iran's gas industry due to the lack of reference prices for exports in the Middle East Henry. This assumption is considered given that the aim of this research is to prioritize Giga- projects and given that the feed rate for all projects follow a same reference. Scenarios facing the international price of natural gas (Henry Hub in America) are shown in Figure 5. Given that the best and the worst cases are investigated in the fuzzy pay off approach, the three scenarios of High oil price, Reference and High oil and gas resource are used in order to create triangular fuzzy numbers as an indicator of mega-investments' revenues.

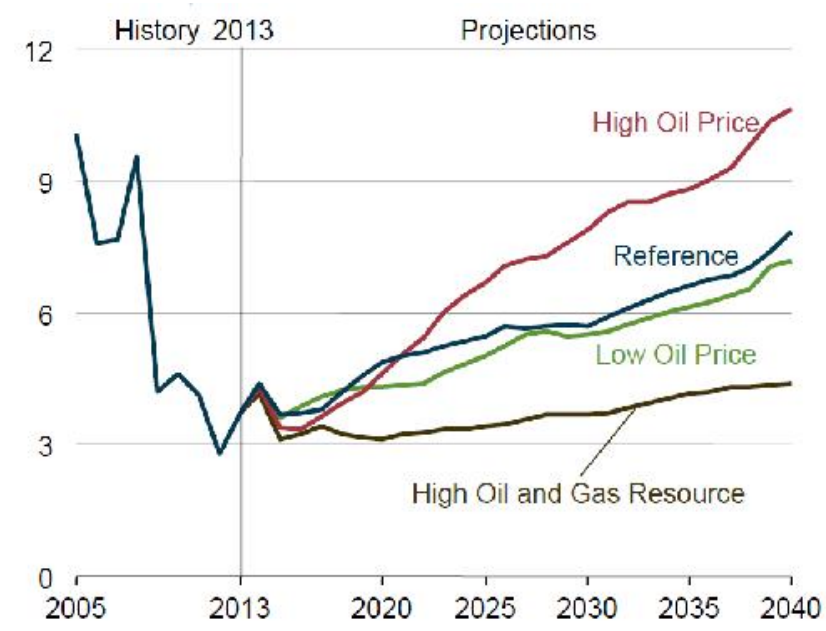

Fig.6. Average Henry Hub spot prices for natural gas in four cases (dollars per million Btu)[27]

\subsection{Gas export scenarios and investment opportunities}

In this section, some mega investments in Iran, as well as their cost and revenue aspects during the period of construction and operation are presented. Given the diversity of projects in Iran's gas industry, one important project is selected from this area, but the method presented in this article can be used to evaluate other projects. Technical and economic information presented in this section has been derived from interviews with experts in Iranian gas industry.

\subsubsection{Iran's Natural gas export to Europe with pipe line}

Currently, two potential paths, each with its own characteristics and requirements, can be considered for the export of Iranian gas to Europe. The first path that passes Turkey, Bulgaria, Romania, Hungary and Slovakia, eventually leads to Austria. However, TurkeyGreece - Italy is considered an alternative to this path. In the second path, the natural gas pipeline has to pass Azerbaijan or Armenia, Georgia, and Ukraine to reach Europe. In both 
paths, the gas pipeline must pass a minimum of 4 countries. In addition to the cost of gas transit that these countries receive, they can be involved in the construction of pipelines and thereby supply a part of their natural gas consumption. The pipeline which passes through Turkey is investigated in this study due to its importance. In order to export Iran's gas from this path, the ninth national gas line is intended. This line is fed by phases 20 and 21 of South Pars. Some characteristics of Iran's export pipeline through Turkey are presented in table 1:

Table 1. Technical and economic characteristics of export line from Iran to Europe

\begin{tabular}{|c|c|c|c|}
\hline Line profile & $\begin{array}{l}\text { Line Length: } 4710 \\
\mathrm{~km}\end{array}$ & $\begin{array}{l}\text { Onshore diameter: } 54 \\
\text { inches }\end{array}$ & $\begin{array}{c}\text { Underwater } \\
\text { diameter: } 34 \text { inches }\end{array}$ \\
\hline \multirow{2}{*}{$\begin{array}{l}\text { Pressure boosting } \\
\text { and control } \\
\text { infrastructures }\end{array}$} & $\begin{array}{l}\text { The number of } \\
\text { pressure boosting } \\
\text { stations: } 27\end{array}$ & $\begin{array}{l}\text { The number of } \\
\text { border stations: } 10 \\
\text { stations }\end{array}$ & $\begin{array}{c}\text { Number of } \\
\text { maintenance centers: } \\
21 \text { centers }\end{array}$ \\
\hline & $\begin{array}{l}\text { Number of } \\
\text { dispatching centers: } 3 \\
\text { center }\end{array}$ & & \\
\hline $\begin{array}{l}\text { Construction and } \\
\text { operation period }\end{array}$ & $\begin{array}{l}\text { Construction period: } \\
4 \text { years }\end{array}$ & $\begin{array}{c}\text { Life of the Line: } 25 \\
\text { years }\end{array}$ & \\
\hline $\begin{array}{l}\text { The total volume of } \\
\text { exported gas }\end{array}$ & $\begin{array}{l}\text { Gas volume: } 32 \\
\text { billion cubic meters } \\
\text { per year }\end{array}$ & & \\
\hline \multirow{2}{*}{$\begin{array}{c}\text { Capital and operating } \\
\text { cost items }\end{array}$} & $\begin{array}{l}\text { The cost of capital: } \\
13 \text { billion dollars }\end{array}$ & $\begin{array}{c}\text { Operating costs: } 3 \% \\
\text { of capital expenditure } \\
\text { in the year }\end{array}$ & Feeding cost \\
\hline & $\begin{array}{l}\text { Transit Price: } 1.66 \\
\text { cents per cubic meter }\end{array}$ & & \\
\hline
\end{tabular}

\subsubsection{Gas injection in oil fields and oil export}

In the projects of natural gas injection to the oil field, the natural gas is extracted from the South Pars gas field and after separating gas liquids it is sent to the intended oil field through pipelines and with the help of pressure boosting stations. In the intended oil field, it is injected into the oil reservoir through drilled wells and with increasing pressure with the help of high-pressure compressors. In these projects, the cost flow includes capital expenditures to develop upstream gas field, upstream operating costs, capital costs of transmission facilities, 
transmission operating costs, capital costs of construction and operation of equipment and facilities required for injection, drilling injection wells and operating costs of injection. Table 2 presents some technical and economic characteristics of the project of injecting natural gas into Aghajari field for the purpose of enhanced crude oil recovery.

Table 2. Technical and economic characteristics of the project of injecting natural gas into Aghajari field

\begin{tabular}{|c|c|c|c|}
\hline Line profile and costs & $\begin{array}{l}\text { Required line length: } \\
60 \mathrm{~km}\end{array}$ & $\begin{array}{l}\text { Line cost: } \$ 25000 \\
\text { per inch-kilometer } \\
\text { with a diameter of } 8 \\
\text { to } 10 \text { inches }\end{array}$ & \\
\hline \multirow[b]{2}{*}{$\begin{array}{l}\text { Injection equipment } \\
\text { profile and costs }\end{array}$} & $\begin{array}{l}\text { The number of } \\
\text { injection wells: } 3 \\
\text { wells in the form of } 2 \\
\text { injection wells and } 1 \\
\text { service well }\end{array}$ & $\begin{array}{l}\text { Cost of each } \\
\text { injection well: } 25 \\
\text { million dollars for } \\
\text { average land and sea }\end{array}$ & $\begin{array}{l}\text { required compressor } \\
\text { capacity: } \\
\text { Approximately } 700 \\
\text { to } 800 \text { horsepower }\end{array}$ \\
\hline & $\begin{array}{l}\text { The cost of } \\
\text { compressor stations: } \\
\$ 3,500 \text { per } \\
\text { horsepower }\end{array}$ & $\begin{array}{l}\text { The cost of gas } \\
\text { processing and oil } \\
\text { separation facilities: } \\
20,000 \text { dollars for the } \\
\text { capacity of each } \\
\text { barrel of crude oil per } \\
\text { day. }\end{array}$ & $\begin{array}{l}\text { BGI for } 230^{\circ} \mathrm{F} \text { and } \\
\text { pressure of } 5000 \text { psi } \\
\text { at Aghajari field: } \\
0.00393 \text { (Q / Q') }\end{array}$ \\
\hline $\begin{array}{l}\text { Construction and } \\
\text { operation period }\end{array}$ & $\begin{array}{l}\text { Construction period: } \\
4 \text { years }\end{array}$ & $\begin{array}{l}\text { The period of } \\
\text { operation: } 25 \text { years }\end{array}$ & $\begin{array}{l}\text { The average time for } \\
\text { the recovery of gas } \\
\text { injection: } 2 \text { years }\end{array}$ \\
\hline $\begin{array}{l}\text { The total volume of } \\
\text { exported gas }\end{array}$ & $\begin{array}{l}\text { The volume of gas } \\
\text { injected: } 12 \text { billion } \\
\text { cubic meters per year }\end{array}$ & Feed costs & \\
\hline
\end{tabular}

\subsubsection{Iran's LNG export}

LNG projects in Iran have been considered since the early 1970s, but with the start of the war between Iran and Iraq, the projects stopped and practically no progress was made on these projects in the 1980s and until after the end of the war[26]. Since the early 2000s, with the 
start of the joint South Pars gas field development projects, new projects have been defined again based on LNG. The main LNG production projects in Iran include 3 main projects of Iran LNG, Pars LNG and Persian LNG. The project of Iran LNG is considered in this study due to its importance. The project consists of 2 production units of 5 million tons of LNG that is fed by Phase 12 of South Pars. The cost flow of this project includes capital expenditures in the upstream gas field development, upstream operating costs, capital spending of dehydration and sweetening and liquefaction unit, operating costs and transportation costs. Table 3 shows some technical and economic characteristics used to evaluate the Iran LNG project:

Table 3. Technical and economic characteristics used to evaluate the Iran LNG project

\begin{tabular}{|c|c|c|c|}
\hline $\begin{array}{l}\text { Capacity and capital } \\
\text { expenditures }\end{array}$ & $\begin{array}{l}2 \text { production lines } \\
\text { with a capacity of } 5 \\
\text { million tons per line }\end{array}$ & $\begin{array}{l}\text { The cost of capital: } \\
800 \text { to } \$ 1,100 \text { per } \\
\text { metric ton annual } \\
\text { production capacity }\end{array}$ & \\
\hline $\begin{array}{l}\text { dehydration and } \\
\text { sweetening } \\
\text { equipment } \\
\text { specifications and } \\
\text { costs }\end{array}$ & $\begin{array}{l}\text { The number of } \\
\text { processing units: } 1 \\
\text { unit }\end{array}$ & $\begin{array}{l}\text { Dehydration units: } 1 \\
\text { unit }\end{array}$ & $\begin{array}{c}\text { Operating costs : } 3 \% \\
\text { of capital expenditure } \\
\text { in the year }\end{array}$ \\
\hline byproducts & $\begin{array}{l}720 \text { thousand tons of } \\
\text { LPG annually with a } \\
\text { price of } \$ 2 \text { more } \\
\text { than oil }\end{array}$ & $\begin{array}{l}300000 \text { tons of } \\
\text { annual NLG gas } \\
\text { liquids with a price } \\
\text { of } \$ 5 \text { more than oil }\end{array}$ & \\
\hline $\begin{array}{l}\text { Construction and } \\
\text { operation period }\end{array}$ & $\begin{array}{l}\text { Construction period: } \\
4 \text { years }\end{array}$ & $\begin{array}{l}\text { The period of } \\
\text { operation: } 25 \text { years }\end{array}$ & \\
\hline $\begin{array}{l}\text { The total volume of } \\
\text { gas used and the } \\
\text { related costs }\end{array}$ & $\begin{array}{l}\text { The volume of gas } \\
\text { injected: } 12 \text { billion } \\
\text { cubic meters per year }\end{array}$ & Feed price & \\
\hline
\end{tabular}

Since the predictions of gas price are made based on Henry Hub spot price, the price of LNG in this article is calculated using the mechanism presented in [28] and using the following equation: 
$\mathrm{P}(\mathrm{LNG})=1.15 * \mathrm{HH}+\mathrm{B}$. Where HH is the Henry Hub futures price on the New York Mercantile Exchange (NYMEX) for the month of lifting and B is a constant agreed between Cheniere and each buyer.

Given that the intended values in the above reference are fixed B between 2.25 to $\$ 3$ per million Btu, B is considered to be 2.5 in this article.

\subsubsection{Export of petrochemical products}

In this study, Giga investment on production and export of methanol from natural gas, according to the users and the volume of investment in this area has been studied to assess petrochemical products' export. Methanol is the world's third most widely used chemical that is widely used in petrochemical downstream industries, including paints, pharmaceuticals, pesticides, clean fuel, and so on. Currently, an average of more than 5 million tons of methanol is produced in the Iranian petrochemical industry annually and is exported to international markets, especially in East Asia and Western Europe. Due to the predictable lack of energy sources, if methanol is accepted as a clean fuel in the future, its consumption will increase. In this paper, investment on a project of 1.7 million tons of methanol has been studied. The capital cost to set up this unit is estimated to be $\$ 700$ million. The construction period of this complex is 4 years and its operation period is considered to be 25 years.

\subsubsection{Iran's GTL export}

The GTL6 technology of converting natural gas to liquids is the newest way through which natural gas can be converted to valuable products such as: methanol, dimethyl ether and other distillation products[29]. Despite the advantages of this technology, the number of large business units in this regard is limited across the world due to high investment costs and today, a small amount of large institutions' resources is allocated to this technology. However, in recent years much attention has been given to the applications of GTL technology for the use of gas resources.

While pipeline and liquefied natural gas (LNG) options focus on the natural gas markets, GTL presents an attractive alternative for gas monetisation for gas-producing countries to expand and diversify into the transportation fuel markets by production of high-quality liquid fuels, particularly diesel (without sulphur and with a high cetane number) and jet fuel [30]. In literature, extensive studies have assessed and compared the profitability of GTL and LNG projects[31-34]. But this research investigates revenues from a GTL mega investment in Iran, according to various scenarios facing the feed price and products of the project. Table 4 shows some technical and economic characteristics to investigate Giga investment on conversion of natural gas to liquid products in Iran. 
Table 4. Technical and economic characteristics used to investigate Giga investment on conversion of natural gas to liquid products in Iran

\begin{tabular}{|c|c|c|c|}
\hline \multirow[t]{2}{*}{$\begin{array}{l}\text { Capacity and capital } \\
\text { costs }\end{array}$} & $\begin{array}{l}\text { A unit with a } \\
\text { capacity of } 70 \\
\text { thousand barrels per } \\
\text { day }\end{array}$ & \multirow[t]{2}{*}{$\begin{array}{l}\text { Capital cost: } 40 \\
\text { thousand dollars per } \\
\text { one barrel production } \\
\text { capacity daily }\end{array}$} & \multirow[t]{2}{*}{$\begin{array}{l}\text { The cost of buying } \\
\text { technical knowledge: } \\
5 \text { to } 10 \% \text { of } \\
\text { investment costs }\end{array}$} \\
\hline & $\begin{array}{l}\text { Capacity: In the first } \\
\text { year } 70 \% \text { and then } \\
5 \% \text { annual increase } \\
\text { in capacity }\end{array}$ & & \\
\hline \multirow[t]{2}{*}{$\begin{array}{l}\text { Specifications and } \\
\text { operational costs }\end{array}$} & $\begin{array}{l}\text { Rich gas refining } \\
\text { cost: } 2.5 \text { cents per } \\
\text { cubic meter }\end{array}$ & $\begin{array}{l}\text { Operating costs: } 3 \% \\
\text { of capital expenditure } \\
\text { in the year }\end{array}$ & $\begin{array}{l}\text { Other variable } \\
\text { operating costs } \\
\text { (Catalyst, use of }\end{array}$ \\
\hline & & $\begin{array}{l}\text { constant non- } \\
\text { operating expenses: } 5 \\
\text { percent of variable } \\
\text { operating costs (cost } \\
\text { of refining and other } \\
\text { variable operation } \\
\text { costs) }\end{array}$ & $\begin{array}{l}\text { facilities, manpower, } \\
\text { etc.): } \$ 3 \text { per barrel }\end{array}$ \\
\hline Products & $\begin{array}{l}76 \% \text { diesel, } 21 \% \\
\text { naphtha, } 3 \% \\
\text { liquefied petroleum } \\
\text { gas }\end{array}$ & \multicolumn{2}{|c|}{$\begin{array}{l}\text { Gasoline prices: with a difference of } \$ 14 \\
\text { from oil } \\
\text { Naphtha prices: with a difference of } \$ 18 \\
\text { from oil } \\
\text { LPG price: } \$ 18 \text { less than crude oil per barrel } \\
\text { and then multiplied by } 11.6 \text { to get the price } \\
\text { per ton }\end{array}$} \\
\hline $\begin{array}{l}\text { Byproducts (per one } \\
\text { million cubic meters } \\
\text { of natural gas per } \\
\text { day) }\end{array}$ & $\begin{array}{l}\text { LPG: } 17,000 \text { tons per } \\
\text { year; Ethan: } 9000 \\
\text { tons per year; sulfur } \\
7 \text { tons per year; } \\
\text { gasoline: } 1,340 \\
\text { barrels per day }\end{array}$ & $\begin{array}{l}\text { Gasoline prices } 30 \% \\
\text { Sulfur price: in } 2010 \\
\text { ton with annua }\end{array}$ & $\begin{array}{l}\text { igher than the price of } \\
\text { il } \\
\text { vas equal to } \$ 140 \text { per } \\
\text { increase of } 2 \%\end{array}$ \\
\hline
\end{tabular}




\begin{tabular}{|l|l|l|l|}
\hline $\begin{array}{l}\text { Construction and } \\
\text { operation period }\end{array}$ & $\begin{array}{l}\text { Construction period: } \\
5 \text { years }\end{array}$ & $\begin{array}{l}\text { The period of } \\
\text { operation: 20 years }\end{array}$ & $\begin{array}{c}\text { Working days: 300 } \\
\text { days }\end{array}$ \\
\hline $\begin{array}{l}\text { The total volume of } \\
\text { gas used and the } \\
\text { related costs }\end{array}$ & $\begin{array}{l}\text { The amount of gas } \\
\text { required to produce a } \\
\text { barrel: } 283 \text { cubic } \\
\text { meters (321.6 cubic } \\
\text { meters of rich gas } \\
\text { obtained from South }\end{array}$ & & \\
& Feed prices & & \\
& & & \\
\hline
\end{tabular}

\subsection{Fuzzy pay off results}

Table 5. Represents internal rate of return and net present value at a discount rate of $10 \%$ for each of the projects under each of the scenarios of oil prices and natural gas

\begin{tabular}{|c|c|c|c|c|c|}
\hline & & & $\begin{array}{l}\text { High oil and } \\
\text { gas resource }\end{array}$ & Reference & High oil price \\
\hline \multirow[t]{2}{*}{1} & \multirow{2}{*}{$\begin{array}{c}\text { Iran's Natural gas } \\
\text { export to Europe with } \\
\text { pipe line }\end{array}$} & IRR & $10.354 \%$ & $11.811 \%$ & $15.366 \%$ \\
\hline & & NPV(\$) & $15,620,303,384$ & $18,625,624,067$ & $28,194,019,086$ \\
\hline \multirow[t]{2}{*}{2} & \multirow{2}{*}{$\begin{array}{l}\text { Gas injection in oil } \\
\text { fields and oil export }\end{array}$} & IRR & $58 \%$ & $71 \%$ & $118 \%$ \\
\hline & & NPV & $11,113,222,016$ & $19,172,863,405$ & $43,639,837,728$ \\
\hline \multirow[t]{2}{*}{3} & \multirow[t]{2}{*}{ Iran's LNG export } & IRR & $41 \%$ & $44 \%$ & $45 \%$ \\
\hline & & NPV & $64,873,980,870$ & $72,171,032,648$ & $87,567,076,760$ \\
\hline \multirow[t]{2}{*}{4} & \multirow{2}{*}{$\begin{array}{c}\text { Export of } \\
\text { petrochemical } \\
\text { products }\end{array}$} & IRR & ---- & $43 \%$ & $46 \%$ \\
\hline & & NPV & - 651,127,758 & $2,930,585,573$ & $3,236,936,828$ \\
\hline \multirow[t]{2}{*}{5} & \multirow[t]{2}{*}{ Iran's GTL export } & IRR & $26 \%$ & $33 \%$ & $51 \%$ \\
\hline & & NPV & $5,289,221,061$ & $10,160,618,037$ & $24,767,131,253$ \\
\hline
\end{tabular}

Given that the amount of investment and the volume of injected gas are different for different projects, the obtained NPV values have been normalized by two methods. In the first method, 
the NPV values of each project in the following scenarios have been divided in order to obtain the NPV value based on the dollar of investment needed. In the second method, NPV values have been divided by the amount of natural gas consumed in the year so that the profitability per injection of each cubic meter of natural gas is calculated. Finally, using the calculations presented in[34], real option value of each project in each of the normalization methods has been obtained and ranked. Tables 6 and 7 show the obtained real option values for mega investments on Iran's gas industry.

Table 6. values of obtained real options for mega investments of Iran's gas industry with normalization based on the amount of gas injected into the project

\begin{tabular}{|c|c|c|c|c|c|c|c|c|c|c|c|c|c|}
\hline & & & & a- alpha & $\bar{a}$ & a+betta & & & & $y=u$ & $\overline{x+z}$ & & \\
\hline & $\begin{array}{r}\text { hig } \\
\text { h } \\
\text { cost }\end{array}$ & $\begin{array}{r}\text { possi } \\
\text { ble } \\
\text { cost }\end{array}$ & $\begin{array}{r}\text { low } \\
\text { cos } \\
t\end{array}$ & $\begin{array}{r}\text { the } \\
\text { whole } \\
\text { pessimist } \\
\text { ic }\end{array}$ & $\begin{array}{r}\text { the } \\
\text { whole } \\
\text { possible }\end{array}$ & $\begin{array}{r}\text { The } \\
\text { whole } \\
\text { optimisti } \\
\text { c }\end{array}$ & $\begin{array}{l}\text { al } \\
\text { ph } \\
\text { a }\end{array}$ & $\begin{array}{l}\text { be } \\
\text { tta }\end{array}$ & $\begin{array}{l}\mathrm{E}( \\
\mathrm{A} \\
+)\end{array}$ & W & $\mathrm{Z}$ & $\begin{array}{l}\text { area } \\
\text { relati } \\
\text { on }\end{array}$ & $\begin{array}{l}\mathrm{R} \\
\mathrm{O} \\
\mathrm{V}\end{array}$ \\
\hline 1 & $\begin{array}{r}- \\
0.2 \\
35\end{array}$ & 0.163 & $\begin{array}{r}- \\
0.1 \\
51\end{array}$ & 0.097 & 0.112 & 0.211 & $\begin{array}{r}0 . \\
01 \\
5\end{array}$ & $\begin{array}{r}0 . \\
09 \\
9\end{array}$ & $\begin{array}{r}0 . \\
12 \\
6\end{array}$ & $\begin{array}{r}68 \\
.6 \\
27\end{array}$ & $\begin{array}{r}6 . \\
67 \\
1\end{array}$ & $\begin{array}{r}1.00 \\
0\end{array}$ & $\begin{array}{r}0 . \\
12 \\
6\end{array}$ \\
\hline 2 & $\begin{array}{r}- \\
0.8 \\
53\end{array}$ & 0.734 & $\begin{array}{r}- \\
0.6 \\
54\end{array}$ & 0.926 & 1.598 & 3.637 & $\begin{array}{r}0 . \\
67 \\
2\end{array}$ & $\begin{array}{r}2 . \\
03 \\
9\end{array}$ & $\begin{array}{r}1 . \\
82 \\
6\end{array}$ & $\begin{array}{r}1 . \\
48 \\
9\end{array}$ & $\begin{array}{r}1 . \\
37 \\
9\end{array}$ & $\begin{array}{r}1.00 \\
0\end{array}$ & $\begin{array}{r}1 . \\
82 \\
6\end{array}$ \\
\hline 3 & $\begin{array}{r}- \\
0.6 \\
03\end{array}$ & 0.602 & $\begin{array}{r}- \\
0.6 \\
02\end{array}$ & 4.865 & 4.010 & 3.604 & $\begin{array}{r}- \\
0 . \\
85 \\
5\end{array}$ & $\begin{array}{r}- \\
0 . \\
40 \\
5\end{array}$ & $\begin{array}{r}4 . \\
08 \\
4\end{array}$ & $\begin{array}{r}- \\
1 . \\
16 \\
9\end{array}$ & $\begin{array}{r}5 . \\
68 \\
8\end{array}$ & $\begin{array}{r}1.00 \\
0\end{array}$ & $\begin{array}{r}4 . \\
08 \\
4\end{array}$ \\
\hline 4 & $\begin{array}{r}- \\
1.1 \\
68\end{array}$ & $\begin{array}{r}- \\
1.034\end{array}$ & $\begin{array}{r}- \\
0.9 \\
09\end{array}$ & -0.440 & 1.981 & 2.189 & $\begin{array}{r}2 . \\
42 \\
2\end{array}$ & $\begin{array}{r}0 . \\
20 \\
7\end{array}$ & $\begin{array}{r}1 . \\
61 \\
5\end{array}$ & $\begin{array}{r}0 . \\
41 \\
3\end{array}$ & $\begin{array}{r}0 . \\
18 \\
2\end{array}$ & $\begin{array}{r}0.97 \\
0\end{array}$ & $\begin{array}{r}1 . \\
56 \\
6\end{array}$ \\
\hline 5 & $\begin{array}{r}- \\
1.1 \\
55\end{array}$ & 1.040 & $\begin{array}{r}0.9 \\
76\end{array}$ & 0.783 & 1.504 & 3.667 & $\begin{array}{r}0 . \\
72 \\
1\end{array}$ & $\begin{array}{r}2 . \\
16 \\
3\end{array}$ & $\begin{array}{r}1 . \\
74 \\
5\end{array}$ & $\begin{array}{r}1 . \\
38 \\
6\end{array}$ & $\begin{array}{r}1 . \\
08\end{array}$ & $\begin{array}{r}1.00 \\
0\end{array}$ & $\begin{array}{r}1 . \\
74 \\
5\end{array}$ \\
\hline
\end{tabular}


Table 7. Values of obtained real options for mega investments of Iran's gas industry with normalization based on the amount of the investment needed for project

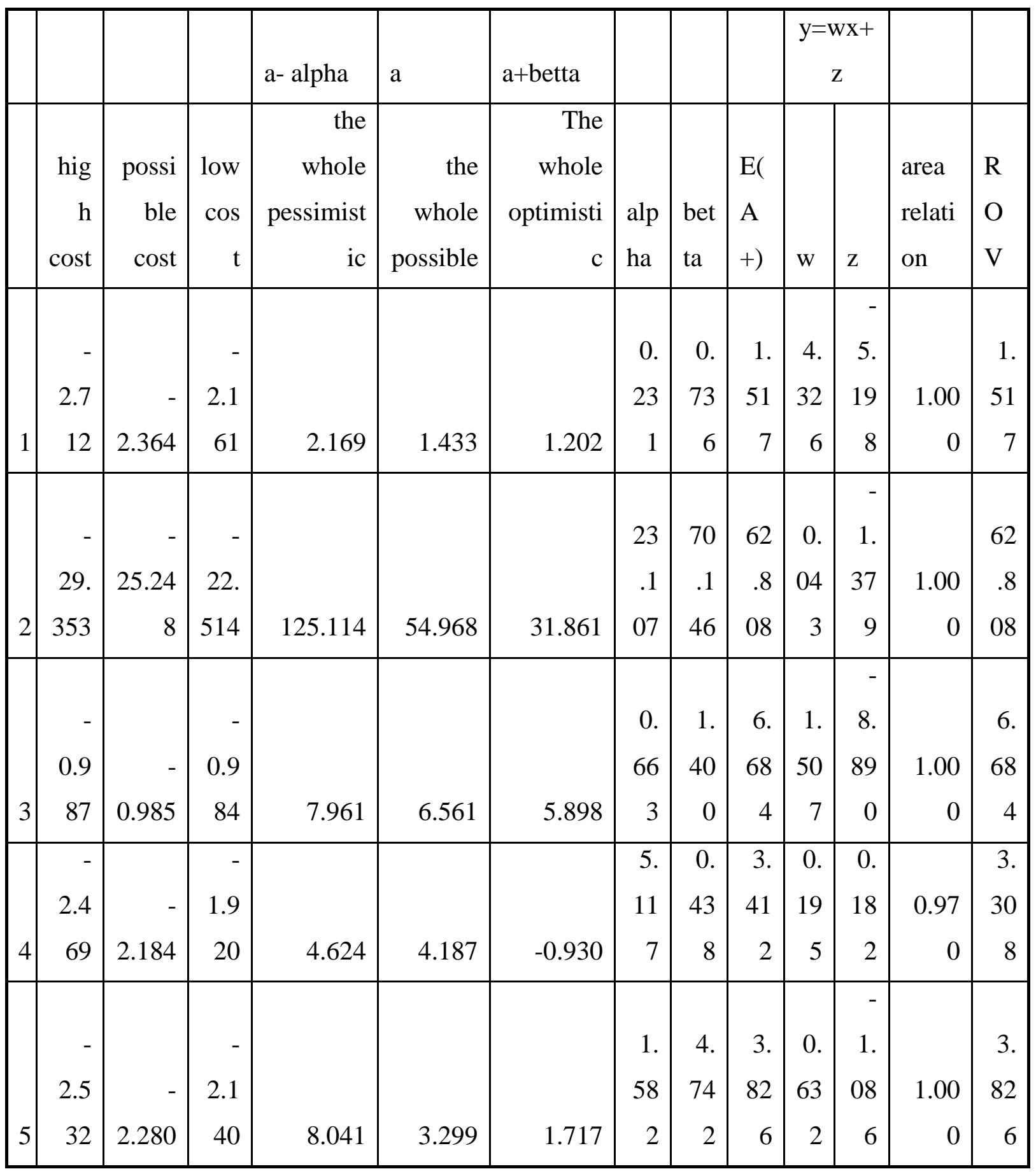

Table 8 shows the ranks obtained for each of the projects taking into account their net present value (NPV) distribution normalization method. 
Table 8. Ranking Giga investment projects in Iran's gas industry

\begin{tabular}{|c|c|c|c|}
\hline & & $\begin{array}{c}\text { normalization based } \\
\text { on the amount of gas } \\
\text { injected into the } \\
\text { project }\end{array}$ & $\begin{array}{c}\text { normalization based } \\
\text { on the amount of the } \\
\text { investment needed } \\
\text { for project }\end{array}$ \\
\hline 1 & $\begin{array}{c}\text { Iran's Natural gas export to Europe with } \\
\text { pipe line }\end{array}$ & 5 & 5 \\
\hline 2 & Gas injection in oil fields and oil export & 3 & 1 \\
\hline 3 & Iran's LNG export & 1 & 2 \\
\hline 4 & Export of petrochemical products & 4 & 3 \\
\hline 5 & Iran's GTL export & 2 & \\
\hline
\end{tabular}

The rate of feed gas is considered constant in this research study. Therefore, any change in the rate can have significant effects on the economic benefits of Giga investments examined. The results shown in Table 8, with the assumption of normalization based on the amount of gas injected, can help analysts to observe ranking of the revenues of projects based on the injections of cubic meter of natural gas as the feed. Obviously, projects that have greater real option value with this assumption can also have higher competitiveness in the case of increase in feed rates. In this case, as can be seen in Table 8, Iran's LNG export is ranked first and Iran's GTL export and Gas injection in oil fields and oil export are next in the ranking. From another perspective, since the amount of revenues according to investments and its funding methods are always one of the concerns of managers and policy-makers, projects in table 8 have also been ranked with the assumption of normalization based on investment needed in the project. Using these results, we can investigate the projects that cause the highest revenues in terms of an investment unit. According to the results of research, Gas injection in oil fields and oil export has the highest economic return for an investment unit and Iran's LNG export and Iran's GTL export are ranked next with a great difference.

\section{DISCUSSION}

Investment in Giga projects has many complexities and ambiguities due to the huge amount of investment needed and the time of projects' implementation and operation and thus, investors must take them into account before starting implementation operations. Uncertainty of future incomes and costs of the project is one the most important issues in investigating 
these kinds of investments and given the long time of the project, there will be the possibility of changes in the conditions governing the project, at the time of formulating the feasibility and business plan. Fuzzy Payoff is used in this paper to evaluate and prioritize Giga project facing the gas industry of Iran. The results show that with regard to the amount of gas injected into the project, the project of Iran's LNG export has the highest economic returns and Iran's GTL export and Gas injection in oil fields are ranked next. Also considering the amount of profit per unit of investment, Injection has the highest economic returns for an investment unit and Iran's LNG export and Iran's GTL export are ranked next with a great difference.

It should be noted that the feed rate in this article is considered constant and Henry Hub price is used due to the nature of gas contracts in the Middle East (not specified format for pricing) and sometimes confidentiality of information. Assumptions for simplifying calculations and predictions are used on other products, which are due to the complexity of the oil price forecast based on futures prices for oil and natural gas. This can change the results. It should also be taken into account that economic investigation won't suffice to start investing in a Giga project and the issues surrounding the project and the conditions of the country, such as the effects of possible sanctions on the achievements of the projects, risks associated with the acquisition of technical knowledge of the theme of the project, or even country's access to financial resources allowing financing of projects with different aspects should also be considered. In addition to the increase of accuracy of analysis input in future studies, the effects of other factors affecting decision-making can be investigated simultaneously with economic analysis of revenues from project implementation.

\section{ACKNOWLEDGEMENTS}

The authors would like to express their appreciation to the National Iranian Gas Company (NIGC) for their funding of this research and thanks to NIGC research staffs for giving us required data.

\section{REFERENCES}

1. Collan, M., Valuation of industrial giga-investments: theory and practice. Fuzzy Economic Review, 2011. 16(1): p. 21.

2. $\quad$ BP, BP Statistical Review of World Energy 2015. 2015, british petroleum Company: www.bp.com/statisticalreview.

3. Petroleum, B., Statistical review of world energy June 2014. 2014. 
4. Katzman, K. Iran sanctions. 2013. DTIC Document.

5. Cengiz, K., Fuzzy Engineering Economics with Applications. 2008, Springer-Verlag Berlin Heidelberg.

6. Keppo, J. and H. Lu, Real options and a large producer: the case of electricity markets. Energy Economics, 2003. 25(5): p. 459-472.

7. Madlener, R. and S. Stoverink, Power plant investments in the Turkish electricity sector: A real options approach taking into account market liberalization. Applied Energy, 2012.97: p. 124-134.

8. Black, F. and M. Scholes, The pricing of options and corporate liabilities. The journal of political economy, 1973: p. 637-654.

9. Lund, M. and J.D. Jensen, A real options approach to biotechnology investment policy-the case of developing a Campylobacter vaccine to poultry. Preventive Veterinary Medicine, 2016. 128: p. 58-69.

10. Jiang, L. and C. Li, Mathematical modeling and methods of option pricing. 2005: World Scientific.

11. Saługa, P.W. and J. Kamiński, Hard coal project valuation based on real options approach: multiplicative vs. arithmetic stochastic process. Gospodarka Surowcami Mineralnymi, 2016. 32(1): p. 25-40.

12. Zmeškal, Z., Application of the fuzzy-stochastic methodology to appraising the firm value as a European call option. European Journal of Operational Research, 2001. 135(2): p. 303-310.

13. Çağrı Tolga, A. and C. Kahraman, Fuzzy multiattribute evaluation of $R \& D$ projects using a real options valuation model. International Journal of Intelligent Systems, 2008. 23(11): p. 1153-1176.

14. Tolga, A.Ç., C. Kahraman, and M.L. Demircan, A Comparative Fuzzy Real Options Valuation Model using Trinomial Lattice and Black-Scholes Approaches: A Call Center Application. Multiple-Valued Logic and Soft Computing, 2010. 16(1-2): p. 135-154.

15. Morgan, H.M. and O. Ngwenyama, Real options, learning cost and timing software upgrades: Towards an integrative model for enterprise software upgrade decision analysis. International Journal of Production Economics, 2015. 168: p. 211-223.

16. Vimpari, J. and S. Junnila, Theory of valuing building life-cycle investments. Building Research \& Information, 2015: p. 1-13. 
17. Mathews, S., V. Datar, and B. Johnson, A practical method for valuing real options: the boeing approach. Journal of Applied Corporate Finance, 2007. 19(2): p. 95-104.

18. Mathews, S. and J. Salmon, Business engineering: a practical approach to valuing high-risk, highreturn projects using real options. Tutorials in operations research, 2007.

19. Collan, M., R. Fullér, and J. Mezei, A fuzzy pay-off method for real option valuation. Advances in Decision Sciences, 2009. 2009.

20. Zadeh, L.A., Fuzzy sets. Information and control, 1965. 8(3): p. 338-353.

21. Şengül, Ü., et al., Fuzzy TOPSIS method for ranking renewable energy supply systems in Turkey. Renewable Energy, 2015. 75: p. 617-625.

22. Lu, J., G. Zhang, and D. Ruan, Multi-objective group decision making: methods, software and applications with fuzzy set techniques. 2007: Imperial College Press.

23. Carlsson, C. and R. Fullér, On possibilistic mean value and variance of fuzzy numbers. Fuzzy sets and systems, 2001. 122(2): p. 315-326.

24. Mathews, S., Valuing high-risk high-return technology projects using real options. The Handbook of Technology Management: Core Concepts, Financial Tools and Techniques, Operations and Innovation Management, 2010. 1: p. 581-600.

25. Anders Rasmus Enevoldsen, A.V.N., Real options valuation of a biotech project using fuzzy numbers, in Institute of Economics. 2011 Copenhagen Business School: studenttheses.cbs.dk. p. 117.

26. Jalilvand, D.R., Iran's Gas Exports: Can Past Failure Become Future Success? 2013: Oxford Institute for Energy Studies.

27. DOE, U., Annual Energy Outlook, with Projections to 2040. Energy Information Administration, DOE/EIA-0383 (2015), 2015.

28. Rogers, H.V. and J. Stern, Challenges to JCC pricing in Asian LNG markets. OIES Paper: NG, 2014. 81.

29. Wood, D.A., C. Nwaoha, and B.F. Towler, Gas-to-liquids (GTL): A review of an industry offering several routes for monetizing natural gas. Journal of Natural Gas Science and Engineering, 2012. 9: p. 196-208.

30. Wood, D., Where We Are: Relationships, Contacts Evolve Along Supply Chain. Oil, Gas \& Energy Law Journal (OGEL), 2006. 4(1).

31. Chedid, R., M. Kobrosly, and R. Ghajar, The potential of gas-to-liquid technology in the energy market: The case of Qatar. Energy Policy, 2007. 35(10): p. 4799-4811. 
32. Araghi, M.K., Z. Kasraei, and A.H. Heidari, Cost-Benefit Analysis of Gas to Liquids Project for the South-Pars Gas Field of Iran. Iranian Journal of Economic Studies, 2013. 2(2): p. 119-136.

33. Dong, L., et al., GTL or LNG: which is the best way to monetize "stranded" natural gas? Petroleum Science, 2008. 5(4): p. 388-394.

34. Khalilpour, R. and I. Karimi, Evaluation of utilization alternatives for stranded natural gas. Energy, 2012. 40(1): p. 317-328.

How to cite this article:

Servati Y, Hassan Ghodsypour S, Shirazi M A. The use of fuzzy real option valuation method to rank giga investment projects on iran's natural gas reserves. J. Fundam. Appl. Sci., 2016, 9(1S), 73-95. 